\title{
PENGARUH PEMBERIAN YOGHURT KEDELAI HITAM (BLACK SOYGHURT) TERHADAP KADAR KOLESTEROL TOTAL DAN TRIGLISERIDA PADA LAKI-LAKI PENDERITA DISLIPIDEMIA USIA 40-55 TAHUN
}

\author{
Santy Sundari, Fillah Fithra Dieny ${ }^{*}$ \\ Program Studi Ilmu Gizi Fakultas Kedokteran Universitas Diponegoro \\ Jl.Dr.Sutomo No.14, Semarang, Telp (024) 8453708, Email : gizifk@undip.ac.id
}

\begin{abstract}
ABSTRCT
Background: Dyslipidemia is a lipid metabolism disorder signed by elevating or decreasing lipid fraction in plasma, one of which the increase total cholesterol and triglyceride. Black soyghurt contains antioxidant anthosianin and isoflavone to prevent lipid oxidation, so it can decrease cholesterol levels.

Objective: This research aimed to identify the effect of black soyghurt for total cholesterol and triglyceride level in dyslipidemia patients.

Method: This study was true experiment with control group pre-test-post-test design. Subjects were obtained by consecutive sampling. Total subjects were 14 persons in each group is first treatment group given black soyghurt $115 \mathrm{ml} /$ day, second treatment group given $225 \mathrm{ml} /$ day and control group without treatment during 21 days. In each group got counseling. Before checking up of blood, subject had to fasting for \pm 10 hours. Total blood cholesterol and triglyceride were examined before and after intervention. Intake of each group were monitored during 21 days. Normality test used Shapiro Wilks. Analysis of total blood cholesterol and triglyceride in each group used paired ttest and wilcoxon. The difference of total blood cholesterol and triglyceride in each group used ANOVA ang Kruskall-Wallis

Result : There was no significant the decreased in three group.Black soyghurt with $115 \mathrm{ml}$ dose decreased total blood cholesterol $1.64 \%$ and triglyceride $7.85 \%$. Black soyghgurt with $225 \mathrm{ml}$ dose decreased total cholesterol $0.05 \%$. There was decrease total cholesterol $2.12 \%$ and triglyceride $13.02 \%$ in control group. There was no significant difference statistically in three group. Some compounding variable have influenced on total cholesterol and triglyceride level in control group and second treatment group including BMI, energy intake, protein, lipid, carbohydrate, cholesterol and fiber.

Conclusions: There was no significant the decreased in three group. Black soyghurt during 21 days with 115 dose decreased total cholesterol $1.64 \%$ and triglyceride $7.85 \% .225 \mathrm{ml}$ dose decreased total cholesterol $0.05 \%$.
\end{abstract}

Keywords: black soyghurt; total cholesterol; triglyceride; dyslipidemia

\begin{abstract}
ABSTRAK
Latar Belakang: Dislipidemia merupakan kelainan metabolisme lipid yang ditandai dengan peningkatan maupun penurunan fraksi lipid dalam plasma, salah satunya adalah peningkatan kadar kolesterol total dan trigliserida. Yoghurt kedelai hitam memiliki kandungan antioksidan yaitu anthosianin dan isoflavon untuk mencegah oksidasi lemak sehingga mampu menurunkan kadar kolesterol.

Tujuan : Penelitian ini bertujuan untuk mengetahui pengaruh pemberian yoghurt kedelai hitam terhadap kadar kolesterol total dan trigliserida pada penderita dislipidemia.

Metode: jenis penelitian ini adalah true experimental dengan rancangan control group pre test- post test design. Subjek penelitian diambil dengan cara concecutive sampling, besar subjek penelitian ini adalah 14 orang pada masing-masing kelompok yaitu kelompok perlakuan I diberikan black soyghurt $115 \mathrm{ml}$, kelompok perlakuan II diberikan $225 \mathrm{ml}$ dan kelompok kontrol tanpa diberikan perlakuan selama 21 hari. Sebelum intervensi masingmasing kelompok diberikan konseling. Subjek penelitian sebelum dilakukan pemeriksaan darah berpuasa selama \pm 10 jam. Kadar kolesterol total dan trigliserida diukur sebelum dan sesudah dilakukan intervensi. Asupan makan masing-masing kelompok dipantau selama 21 hari. Normalitas data diuji dengan Shapiro Wilks. Analisis kadar kolesterol total dan trigliserida pada masing-masing kelompok menggunakan uji paired-t-test dan wilcoxon. Perbedaan kadar kolesterol total dan trigliserida pada masing-masing kelompok menggunakan uji ANOVA dan uji kruskall-wallis.

Hasil: Pada ketiga kelompok tidak terdapat penurunan yang signifikan. Yoghurt kedelai hitam dosis $115 \mathrm{ml}$ mampu menurunkan kadar kolesterol total sebesar 1.64\% dan trigliserida 7.85\%. Dosis 225 ml mampu menurunkan kadar kolesterol total $0.05 \%$. Pada kelompok kontrol terjadi penurunan kadar kolesterol total $2.12 \%$ dan trigliserida $13.02 \%$. Beberapa variabel perancu terrnyata memiliki pengaruh terhadap kadar kolesterol total dan trigliserida pada kelompok kontrol dan perlakuan II antara lain IMT, asupan energi, protein, lemak, karbohidrat, kolesterol dan serat.
\end{abstract}

${ }^{*}$ Penulis Penanggungjawab 
Kesimpulan : Pada ketiga kelompok tidak terdapat penurunan yang signifikan. Pemberian yoghurt kedelai hitam selama 21 hari dengan dosis $115 \mathrm{ml}$ mampu menurunkan kadar kolesterol total sebesar $1.64 \%$ dan trigliserida 7.85\%. Dosis $225 \mathrm{ml}$ mampu menurunkan kadar kolesterol total sebesar $0.05 \%$.

Kata kunci: yoghurt kedelai hitam ; kolesterol total; trigliserida; dislipidemia

\section{PENDAHULUAN}

Dislipidemia metabolisme lipid yang ditandai dengan peningkatan maupun penurunan fraksi lipid dalam plasma. Kelainan fraksi lipid yang paling utama adalah kenaikan kolesterol total, kolesterol low density lipoprotein (LDL) kenaikan kadar trigliserida dan penurunan kadar high density lipoprotein (HDL). Kenaikan kadar kolesterol dan trigliserida termasuk faktor risiko terjadinya dislipidemia. ${ }^{1}$ Berdasarkan penelitian di empat kota besar di Indonesia pada orang yang berusia diatas 55 tahun ditemukan paling banyak yaitu 56\% dikota Padang dan Jakarta sedangkan di Kota Bandung sebesar 52,2\%, dan Yogyakarta yaitu $27,7 \% .^{2}$ Dislipidemia merupakan salah satu masalah yang penting karena merupakan faktor resiko utama terjadinya penyakit jantung koroner. Menurut hasil Riset Kesehan Dasar (RISKESDAS) 2007 prevalensi Nasional penyakit jantung di Indonesia adalah $7,2 \%$, sementara prevalensi di Jawa Tengah yaitu $8,4 \%$. $^{3}$

Pengaturan pola makan dan modifikasi diet merupakan salah satu cara untuk membantu dalam menekan peningkatan kadar lipid darah. Pengaturan pola makan yang dianjurkan yaitu dengan membatasi konsumsi makanan yang mengandung kolesterol dan lemak tinggi terutama lemak jenuh. ${ }^{4}$ Selain membatasi makanan yang tinggi kolesterol dan lemak, mengkonsumsi jenis makanan yang memiliki manfaat untuk menurunkan kadar kolesterol juga diperlukan. Salah satu jenis bahan makanan tersebut seperti kedelai. $^{5}$

Penelitian metaanalisis terhadap 38 uji klinis menyimpulkan bahwa protein pada kacang kedelai mampu menurunkan kadar kolesterol total sebesar 3,8-9,3\% dan trigliserida 5,3-12,9\%. ${ }^{6}$ Penelitian lain yang dilakukan pada hwan coba yang diberikan pakan tinggi lemak yang dilakukan di Universitas Airlangga membuktikan susu kedelai hitam pada dosis $1,5 \mathrm{ml}$ selama 28 hari mampu menurunkan kadar kolesterol total. Salah satu jenis kacang kedelai yang mampu menurunkan kadar kolesterol adalah kedelai hitam. Kedelai hitam mampu menurunkan kadar kolesterol karena memiliki kandungan antioksidan yang tinggi yaitu anthosianin dan isoflavon. ${ }^{7}$
Produk olahan kacang kedelai memiliki kandungan antioksidan yang lebih tinggi daripada kedelai tanpa pengolahan. ${ }^{8}$ Salah satu produk yang dapat diolah dari kacang kedelai hitam adalah black soyghurt.

Black soyghurt merupakan produk fermentasi susu kedelai hitam oleh bakteri asam laktat. Soyghurt memiliki keunggulan dibandingkan yoghurt susu sapi karena kedelai memiliki kandungan antioksidan yang lebih tinggi untuk mencegah oksidasi lemak. Selain itu, hasil fermentasi susu kedelai tidak mengandung laktosa maupun kolesterol sehingga baik untuk kesehatan. Konsumsi soyghurt juga memiliki manfaat bagi keseimbangan ekosistem pada saluran intestinal dengan meningkatkan populasi probiotik dan menurunkan populasi bakteri patogen. ${ }^{9}$

Penelitian terdahulu yang dilakukan pada tikus Sprague Dawley hiperkolesterolemia, diperoleh hasil bahwa pemberian Black soyghurt sebanyak $2 \mathrm{ml}, 3 \mathrm{ml}$, dan $4 \mathrm{ml}$ selama 21 hari mampu menurunkan kadar kolesterol kolesterol secara signifikan. Penurunan kadar kolesterol paling bermakna terjadi pada kelompok perlakuan pemberian Black soyghurt $2 \mathrm{ml}$ dan $4 \mathrm{ml}$.Jika dosis ini dikonversikan sesuai kebutuhan manusia yang memiliki Berat Badan 70kg maka diperoleh dosis $115 \mathrm{ml}$ dan 225, dosis ini didapatkan dari hasil kali konversi dosis pada tikus dengan bilangan konversi $56,0 .^{10}$

Pemilihan subjek penelitian di lingkungan kerja kantor Sekretariat Daerah Provinsi Jawa Tengah dengan subjek berjenis kelamin laki-laki usia 40 tahun keatas dikarenakan risiko terjadinya dislipidemia pada laki-laki lebih besar dibandingkan dengan wanita karena pada usia produktif wanita memiliki efek perlindungan dari hormon esterogen, sementara pada laki-laki hormon testosteron mempercepat timbulnya penyakit aterosklerosis. Pada laki-laki usia 40 tahun keatas merupakan usia berisiko mengalami dislipidemia. ${ }^{1,11}$ Selain itu, subjek penelitian dipilih berdasarkan aktivitas yang rendah. Aktivitas fisik yang rendah merupakan salah satu dari faktor risiko yang dapat mengakibatkan dislipidemia dan pegawai negeri sipil dapat mewakili kelompok dengan aktifitas fisik yang rendah.

\section{TUJUAN}


Berdasarkan latar belakang penelitian ini bertujuan untuk mengetahui pengaruh pemberian yoghurt kedelai hitam terhadap kadar kolesterol total pada laki-laki usia 40-55 tahun.

\section{METODE}

Jenis penelitian ini true experiment dengan control group pre test- post test design. Penelitian ini dilakukan di Kantor Sekretariat Daerah Provinsi Jawa Tengah. Populasi dalam penelitian ini adalah karyawan Kantor Sekretariat Daerah Provinsi Jawa Tengah yang menderita dislipidemia. Besar subjek dihitung dengan rumus uji hipotesis terhadap rerata dua populasi independen dengan tingkat kemaknaan 95\% dan kekuatan uji 90\%. Pada penelitian ini perbedaan klinis yang ingin dicapai peneliti sebesar $15 \mathrm{mg} / \mathrm{dl}$ dengan standar deviasi yang digunakan berdasarkan penelitian sebelumnya adalah 11 sehingga didapatkan jumlah subjek sebanyak 14 orang.

Subjek penelitian merupakan karyawan Kantor Sekretariat Daerah Provinsi Jawa Tengah, dengan kriterian inklusi berjenis kelamin laki-laki, usia 40-55 tahun, memilik indeks massa tubuh (IMT) $\geq 18,5 \mathrm{~kg} / \mathrm{m}^{2}$, bersedia menjadi subjek penelitian dengan mengisi informed consent dan dapat diajak berkomunikasi, merokok tidak lebih dari 10 batang/hari, mengkonsumsi kopi< 3 gelas/ hari, tidak mengkonsumsi alkohol, tidak dalam keadaan sakit atau dalam perawatan dokter berkaitan dengan penyakit jantung koroner, diabetes melitus, hipertensi, gagal ginjal dan penyakit kronik lainnya, tidak mengkonsumsi obatobat-obatan antidislipidemia selama penelitian, memiliki kadar kolesterol total $\geq 200 \mathrm{mg} / \mathrm{dl}$, memiliki kadar trigliserida $\geq 150 \mathrm{mg} / \mathrm{dl}$, bersedia mengikuti proses konseling gizi sebelum dilakukan pemberian intervensi.

Subjek penelitian diambil dengan menggunakan metode concecutive sampling yaitu semua subjek yang datang dan memenuhi kriteria inklusi dimasukkan dalam penelitian sampai jumlah subjek yang diperlukan terpenuhi. Pada subjek penelitian dilakukan skrining awal dan pemeriksaan darah sehingga diperoleh sebanyak 42 orang yang memenuhi kriteria inklusi untuk menjadi subjek penelitian. Subjek dibagi menjadi 3 kelompok dengan metode simple random sampling, yang terdiri atas satu kelompok kontrol dan dua kelompok perlakuan, masing-masing kelompok terdiri dari 14 orang. Kelompok perlakuan pertama mendapatkan yoghurt kedelai hitam sebanyak $115 \mathrm{ml}$ dan kelompok perlakuan kedua mendapatkan yoghurt kedelai hitam sebanyak $225 \mathrm{ml}$.
Subjek pada awal dilakukan pemeriksaan kolesterol total dan trigliserida. Semua subjek penelitian dengan kadar kolesterol total dan trigliserida yang tinggi sebelum dilakukan intervensi terlebih dahulu diberikan konseling mengenai dislipidemia dan pengaturan pola makan.

Pemberian yoghurt kedelai hitam dilakukan selam 21 hari, dan pada kelompok kontrol, subjek tidak diberikan perlakuan. Pemberian yoghurt kedelai hitam dilakukan secara langsung oleh peneliti. Kepatuhan konsumsi yoghurt kedelai hitam dipantau dengan mengunakan formulir daya terima. Pada awal pemberian yoghurt sebagian subjek tidak bersedia menghabiskan dikarenakan rasa yoghurt yang asam tetapi setelah peneliti memberikan pengertian tentang yoghurt pada hari berikutnya subjek bersedia menghabiskan yoghurt yang diberikan. Konsumsi makan sehari-hari subjek untuk setiap kelompok diberikan konseling gizi tentang dislipidemia dan pengaturan pola makan pada dislipidemia oleh peneliti. Catatan asupan makan dilakukan sebelum intervensi dan selama intervensi berlangsung dengan menggunakan metode food recall 24 jam dan food record selama 21 hari.

Variabel bebas dalam penelitian ini adalah pemberian yoghurt kedelai hitam dan variabel terikan adalah kadar kolesterol total dan trigliserida penderita dislipidemia. Kadar kolesterol total dan trigliserida dianalisis dengan pemeriksaan laboratorium menggunakan metode Cholesterol Oxidase Phenol Aminoantipyrin (CHOD-PAP) dan GPO-PAP. Darah setiap subjek penelitian diambil oleh petugas laboratorium setelah subjek berpuasa selama $\pm 10 \mathrm{jam}$, pengambilan darah dilakukan sebelum dan sesudah dilakukan intervensi. Data asupan makan subjek dianalisis dengan menggunakan program nutrisurvey 2005.

Data yang telah ada diuji normalitasnya dengan uji Shapiro-Wilk.Analisis deskriptif digunakan untuk melihat gambaran karakteristik subjek serta asupan makan subjek selama penelitian. Perbedaan kadar kolesterol total sebelum dan sesudah perlakuan diuji dengan Paired t-test pada kelompok kontrol dan perlakuan 1 dan uji Wilcoxon untuk data pada kelompok perlakuan 2 karena data tidak berdistribusi normal. Perbedaan kadar kolesterol trigliserida pada ketiga kelompok menggunakan uji Wilcoxon. Perbedaan pengaruh konsumsi Black soyghurt terhadap kadar kolesterol total dianalisis menggunakan uji ANOVA, sementara terhadap kadar kolesterol trigliserida dianalisis dengan menggunakan uji 
Kruskall-Wallis. Hubungan kadar kolesterol dan trigliserida dengan faktor-faktor yang mempengaruhi seperti usia, IMT dan asupan selama intervensi menggunakan uji regresi ganda.
HASIL PENELITIAN

Karakteristik Subjek

Gambaran karakteristik subjek berdasarkan usia dan status gizi subjek sebelum penelitian

Tabel 1. Karakteristik subjek penelitian

\begin{tabular}{|c|c|c|c|c|c|c|}
\hline \multirow[t]{2}{*}{ Karakteristik subjek } & \multicolumn{2}{|c|}{$\begin{array}{c}\text { Kontrol } \\
(n=14)\end{array}$} & \multicolumn{2}{|c|}{$\begin{array}{l}\text { Perlakuan I } \\
(\mathrm{n}=14\end{array}$} & \multicolumn{2}{|c|}{$\begin{array}{c}\text { Perlakuan } \\
\text { II } \\
(\mathrm{n}=14)\end{array}$} \\
\hline & $\mathrm{n}$ & $\%$ & $\mathrm{n}$ & $\%$ & $\mathrm{n}$ & $\%$ \\
\hline \multicolumn{7}{|l|}{ Usia } \\
\hline $40-50$ tahun & 6 & 42.86 & 5 & 35.71 & 7 & 50 \\
\hline 51-55 tahun & 8 & 57.14 & 9 & 64.29 & 7 & 50 \\
\hline \multicolumn{7}{|l|}{ Status gizi } \\
\hline Normal $\left(18,5-22,9 \mathrm{~kg} / \mathrm{m}^{2}\right)$ & 4 & 28.57 & 2 & 14.29 & 2 & 14.28 \\
\hline $\begin{array}{l}\text { Overweight } \\
\left.\mathrm{kg} / \mathrm{m}^{2}\right)\end{array}$ & 3 & 21.43 & 5 & 35.71 & 4 & 28.57 \\
\hline $\begin{array}{l}\text { Obesitas } \\
\left.\mathrm{kg} / \mathrm{m}^{2}\right)\end{array}$ & 7 & 50 & 6 & 42.86 & 6 & 42.86 \\
\hline Obesitas II $\left(\geq 30 \mathrm{~kg} / \mathrm{m}^{2}\right)$ & 0 & 0 & 1 & 7.14 & 2 & 14.29 \\
\hline
\end{tabular}

Tabel 1 menunjukkan subjek sebagian besar berada pada kelompok usia 51-60 tahun $(57,14 \%)$ dan sebagian besar memiliki kategori status gizi overweight dan Obesitas I (73,8\%).

\section{Keadaan subjek penelitian pada awal penelitian}

Keadaan subjek penelitian ditampilkan untuk mengetahui homogenitas variabel pada ketiga kelompok.

Tabel 2. Keadaan subjek pada awal penelitian

\begin{tabular}{|c|c|c|c|c|c|c|}
\hline \multirow[t]{2}{*}{ Variabel } & \multicolumn{3}{|c|}{ Rerata (mean \pm SD) } & \multirow[t]{2}{*}{$\min$} & \multirow[t]{2}{*}{ maks } & \multirow[t]{2}{*}{$\mathrm{p}$} \\
\hline & Kontrol & Perlakuan I & Perlakuan II & & & \\
\hline Usia (tahun) & $50 \pm 4.56$ & $49.5 \pm 5.17$ & $49.57 \pm 4.38$ & 40 & 55 & $\begin{array}{c}0.55 \\
9^{\mathrm{a}}\end{array}$ \\
\hline IMT awal $\left(\mathrm{kg} / \mathrm{m}^{2)}\right.$ & $24.76 \pm 2.50$ & $25.65 \pm 3.02$ & $26.6 \pm 4.05$ & $\begin{array}{c}20 . \\
2\end{array}$ & 36.7 & $\begin{array}{c}0.33 \\
3^{\mathrm{a}}\end{array}$ \\
\hline $\begin{array}{l}\text { Kolesterol awal } \\
(\mathrm{mg} / \mathrm{dl})\end{array}$ & $\begin{array}{l}239.29 \pm 35 . \\
16\end{array}$ & $\begin{array}{l}228.21 \pm 22.0 \\
7\end{array}$ & $\begin{array}{l}225.93(211.50- \\
266)\end{array}$ & 201 & 315 & $\begin{array}{c}0.56 \\
7^{b}\end{array}$ \\
\hline $\begin{array}{l}\text { Trigliserida awal } \\
(\mathrm{mg} / \mathrm{dl})\end{array}$ & $\begin{array}{l}166.07 \pm 96 . \\
27\end{array}$ & $\begin{array}{l}207.79 \pm 132 . \\
76\end{array}$ & $190.79 \pm 107.12$ & 65 & 544 & $\begin{array}{c}0.62 \\
1^{\mathrm{a}}\end{array}$ \\
\hline
\end{tabular}

${ }^{\mathrm{b}}$ Uji Kruskall-Wallis

Tabel 2 menunjukkan tidak ada perbedaan trigliserida pada ketiga kelompok sebelum usia, IMT awal, kadar kolesterol total dan kadar dilakukan intervensi ( $p>0.05)$.

Tabel 3. Kadar kolesterol total dan trigliserida pada awal penelitian

\begin{tabular}{llccccccc}
\hline Variabel & Kategori & \multicolumn{2}{l}{ Kontrol } & \multicolumn{3}{c}{ Perlakuan I } & \multicolumn{2}{c}{$\begin{array}{c}\text { Perlakuan } \\
\text { II }\end{array}$} \\
\cline { 3 - 9 } & & & & & & $\mathrm{n}$ & $\%$ \\
\hline Kolesterol total & Tinggi & $>200$ & 14 & 100 & 14 & 100 & 14 & 100 \\
$(\mathrm{mg} / \mathrm{dl})$ & Normal & $<200$ & 0 & - & 0 & - & 0 & - \\
Trigliserida (mg/dl) & Tinggi & $>150$ & 6 & 42.86 & 8 & 57.14 & 9 & 64.19 \\
& Normal & $<150$ & 8 & 57.14 & 6 & 42.86 & 5 & 35.71 \\
\hline
\end{tabular}




\section{Asupan makan sebelum intervensi}

Asupan makan sebelum intervensi ditampilkan untuk mengetahui asupan yang terjadi pada subjek penelitian sebelum intervensi dilakukan. Perbedaan asupan pada ketiga kelompok dapat dilihat pada tabel 4 .

Tabel 4. Asupan makan sebelum intervensi

\begin{tabular}{|c|c|c|c|c|c|c|c|c|}
\hline \multirow[t]{2}{*}{ Asupan makan } & \multirow[t]{2}{*}{ Kategori } & \multicolumn{2}{|c|}{ Kontrol } & \multicolumn{2}{|c|}{$\begin{array}{l}\text { Perlakuan } \\
\text { I }\end{array}$} & \multicolumn{2}{|c|}{ Perlakuan II } & \multirow[t]{2}{*}{$\mathrm{p}$} \\
\hline & & $\mathrm{n}$ & $\%$ & $\mathrm{n}$ & $\%$ & $\mathrm{n}$ & $\%$ & \\
\hline \multirow[t]{3}{*}{ Energi (kkal) } & Kurang & 14 & 100 & 13 & $\begin{array}{c}92.8 \\
6\end{array}$ & 14 & 100 & $\underset{\mathrm{a}}{0.053}$ \\
\hline & Cukup & - & & 1 & 7.14 & - & & \\
\hline & Lebih & - & & - & & - & & \\
\hline \multirow[t]{3}{*}{ Protein (gram) } & Kurang & 8 & $\begin{array}{c}57.1 \\
4\end{array}$ & 9 & $\begin{array}{c}64.2 \\
9\end{array}$ & 5 & $\begin{array}{c}35.7 \\
1\end{array}$ & $\underset{\mathrm{b}}{0.080}$ \\
\hline & Cukup & 4 & $\begin{array}{c}28.6 \\
7\end{array}$ & 4 & $\begin{array}{c}28.5 \\
7\end{array}$ & 9 & $\begin{array}{c}64.2 \\
9\end{array}$ & \\
\hline & Lebih & 2 & $\begin{array}{c}14.2 \\
9\end{array}$ & 1 & 7.14 & - & & \\
\hline \multirow[t]{3}{*}{ Lemak (gram) } & Kurang & 11 & $\begin{array}{c}78.5 \\
7\end{array}$ & 12 & $\begin{array}{c}85.7 \\
1\end{array}$ & 13 & $\begin{array}{c}92.8 \\
6\end{array}$ & $\underset{\mathrm{a}}{0.065}$ \\
\hline & Cukup & 3 & $\begin{array}{c}21.4 \\
3\end{array}$ & 2 & $\begin{array}{c}14.2 \\
9\end{array}$ & 1 & 7.14 & \\
\hline & Lebih & - & & - & & - & & \\
\hline \multirow[t]{3}{*}{ Karbohidrat (gram) } & kurang & 14 & 100 & 14 & 100 & 14 & 100 & 0.185 \\
\hline & Cukup & - & & - & & - & & \\
\hline & Lebih & - & & - & & - & & \\
\hline \multirow[t]{2}{*}{ Kolesterol (mg) } & $>200$ & 7 & 50 & 7 & 50 & 9 & $\begin{array}{c}64.2 \\
9\end{array}$ & $\underset{\mathrm{b}}{0.998}$ \\
\hline & $<200$ & 7 & 50 & 7 & 50 & 5 & $\begin{array}{c}35.7 \\
1 \\
\end{array}$ & \\
\hline \multirow[t]{2}{*}{ Serat (gram) } & $>20$ & - & & - & & - & & $\underset{\mathrm{a}}{0.012}$ \\
\hline & $<20$ & 14 & 100 & 14 & 100 & 14 & 100 & \\
\hline
\end{tabular}

${ }^{a}$ Uji ANOVA

${ }^{\mathrm{b}}$ Uji Kruskall-Wallis

Asupan sebagian besar subjek penelitian dalam kategori kurang yaitu asupan energi, protein, lemak dan karbohidrat dikarenakan pengambilan data dilakukan pada awal bulan puasa sehingga asupan subjek peneitian cenderung rendah. Asupan kolesterol subjek penelitian sebagian besar > 200 mg dan asupan serat pada semua subjek menunjukkan <20 gram.

\section{Asupan makan selama Intervensi}

Asupan makan selama intervensi ditampilkan untuk mengetahui asupan makan selama intervensi pada masing-masing kelompok dapat dilihat pada tabel 5 .

Tabel 5. Asupan makan selama intervensi

\begin{tabular}{llccccccc}
\hline Asupan zat gizi & Kategori & \multicolumn{2}{c}{ Kontrol } & \multicolumn{2}{c}{ Perlakuan I } & \multicolumn{2}{c}{ Perlakuan II } & $\mathrm{p}$ \\
\cline { 3 - 9 } & & $\mathrm{n}$ & $\%$ & $\mathrm{n}$ & $\%$ & $\mathrm{n}$ & $\%$ & \\
\hline Energi (kkal) & Kurang & 14 & 100 & 14 & 100 & 14 & 100 & $0.298^{\mathrm{a}}$ \\
& Cukup & - & & - & & - & & \\
& Lebih & - & & - & & - & & \\
\hline Protein (gram) & Kurang & 11 & 78.5 & 12 & 85.71 & 11 & 78.57 & $0.330^{\mathrm{b}}$
\end{tabular}




\begin{tabular}{llccccccc}
\hline & Cukup & 2 & 14.2 & 2 & 14.29 & 3 & 21.43 & \\
& & 9 & & & & & \\
& Lebih & 1 & 7.14 & - & & - & & \\
\hline Lemak (gram) & Kurang & 13 & 92.8 & 14 & 100 & 14 & 100 & $0.571^{\mathrm{a}}$ \\
& Cukup & 1 & 7.14 & - & & - & & \\
& Lebih & - & & - & & - & & \\
\hline Karbohidrat & Kurang & 14 & 100 & 14 & 100 & 14 & 100 & $0.075^{\mathrm{a}}$ \\
(gram) & Cukup & - & & - & & - & & \\
\hline Kolesterol (mg) & Lebih & - & & - & & - & & \\
& $>200$ & 4 & 28.5 & 6 & 42.86 & 5 & 35.71 & $0.704^{\mathrm{a}}$ \\
& $<200$ & 10 & 71.4 & 8 & 57.14 & 9 & 64.19 & \\
& $>20$ & - & & - & & - & & $0.012^{\mathrm{b}}$ \\
\hline Serat (gram) & $>20$ & 14 & 100 & 14 & 100 & 14 & 100 & \\
\hline
\end{tabular}

${ }^{a}$ Uji ANOVA

${ }^{\mathrm{b}}$ Uji Kruskall-Wallis

Tabel 5 menunjukkan tidak ada perbedaan asupan energi, protein, lemak, karbohidrat dan kolesterol antara ketiga kelompok selama penelitian $(p>0.05)$. Namun, terdapat perbedaam asupan serat antara ketiga kelompok selama penelitian $(\mathrm{p}<0.05)$.

\section{Perbedaan Asupan Makan sebelum dan selama Intervensi}

Perbedaan asupan makan untuk membandingkan asupan makan sebelum dan selama intervensi pada masing-masing kelompok dapat dilihat pada tabel 6.

Tabel 6. perbedaan asupan makan sebelum dan selama intervensi

\begin{tabular}{lllll}
\hline Kelompo & ksupan zat gizi & \multicolumn{2}{c}{ Rerata (mean \pm SD) } & p \\
\cline { 3 - 4 } & & \multicolumn{1}{c}{ Sebelum } & \multicolumn{1}{c}{ Selama } & \\
\hline Kontrol & Energi (kkal & $1058.36 \pm 282.42$ & $901.82 \pm 147.70$ & $0.061^{\mathrm{a}}$ \\
& Protein (gram) & $40.31 \pm 12.01$ & $39.40 \pm 9.60$ & $0.820^{\mathrm{a}}$ \\
& Lemak (gram) & $33.59 \pm 15.67$ & $28.24 \pm 10.56$ & $0.256^{\mathrm{a}}$ \\
& Karbohidrat & $156.59(136.05-50.38)$ & $125.15 \pm 24.13$ & $0.016^{\mathrm{b}}$ \\
& (gram) & & & ${ }^{*}$ \\
& Kolesterol (mg) & $251.04 \pm 208.49$ & $138.12 \pm 120.34$ & $0.053^{\mathrm{a}}$ \\
& Serat (gram) & $8.58 \pm 4.02$ & $7.58 \pm 4.69$ & $0.260^{\mathrm{a}}$ \\
\hline perlakuan & Energi (kkal & $1306.46 \pm 442.95$ & $955.75 \pm 220.99$ & $0.002^{\mathrm{a}^{*}}$ \\
I & & & & \\
& Protein (gram) & $48.57(41.85-17.20)$ & $39.39(31.89-$ & $0.009^{\mathrm{b}}$ \\
& & & $7.98)$ & \\
& Lemak (gram) & $47.41 \pm 21.42$ & $31.50 \pm 9.74$ & $0.008^{\mathrm{a}^{*}}$ \\
& Karbohidrat & $179.09 \pm 56.66$ & $137.51 \pm 33.43$ & $0.003^{\mathrm{a}^{*}}$ \\
& (gram) & & & \\
& Kolesterol (mg) & $247.63(186.30-$ & $175.02 \pm 122.42$ & $0.158^{\mathrm{b}}$ \\
& & $200.09)$ & & \\
& Serat (gram) & $7.35 \pm 2.72$ & $8.12 \pm 1.82$ & $0.133^{\mathrm{a}}$ \\
\hline Perlakuan & Energi (kkal & $1371.16 \pm 293.64$ & $1039.03 \pm 293.48$ & $0.002^{\mathrm{a}^{*}}$ \\
II & & & & \\
& Protein (gram) & $49.74 \pm 12.06$ & $36.25 \pm 10.66$ & $0.001^{\mathrm{a}^{*}}$ \\
& Lemak (gram) & $47.54 \pm 14.74$ & $31.47 \pm 7.23$ & $0.005^{\mathrm{a}^{*}}$ \\
& Karbohidrat & $191.60 \pm 59.90$ & $158.04 \pm 49.92$ & $0.047^{\mathrm{a}^{*}}$ \\
& (gram) & & &
\end{tabular}




\begin{tabular}{clll} 
Kolesterol (mg) & $237.88 \pm 147.97$ & $169.84 \pm 133.38$ & $0.104^{\mathrm{a}}$ \\
Serat (gram) & $11.03 \pm 2.53$ & $11.67 \pm 4.02$ & $0.558^{\mathrm{a}}$ \\
\hline
\end{tabular}

${ }^{a}$ Uji Paired t test * beda bermakna

${ }^{\mathrm{b}}$ Uji Wilcoxon ${ }^{*}$ beda bermakna

Tabel 6 menunjukkan pada kelompok kontrol terdapat perbedaan karbohidrat yang bermakna. Pada kelompok perlakuan I perbedaan asupan yang bermakna terdapat pada asupan energi, protein, lemak dan karbohidrat. Pada kelompok II terjadi perbedaan asupan energi, protein, lemak dan karbohidrat yang bermakna.

\section{Perubahan Asupan Makan}

Perubahan asupan makan untuk mengetahui perubahan asupan makan sebelum dan selama intervensi dapat dilihat pada tabel 6 .

Tabel 7. Perubahan asupan makan sebelum dan selama intervensi

\begin{tabular}{|c|c|c|c|c|}
\hline Variabel & Kontrol & Perlakuan I & Perlakuan II & $\mathrm{p}$ \\
\hline$\Delta$ Asupan Energi & $-156.55 \pm 285.23$ & - & - & $0.208^{\mathrm{a}}$ \\
\hline & & $350.71 \pm 332.44$ & $332.12 \pm 317.54$ & \\
\hline$\Delta$ Asupan Protein & $-0.92 \pm 14.81$ & $-14.18 \pm 16.39$ & $-13.48 \pm 12.00$ & $0.247^{\mathrm{a}}$ \\
\hline$\Delta$ Asupan Lemak & $-5.35 \pm 16.85$ & $-15.91 \pm 18.90$ & $-16.07 \pm 17.67$ & $0.203^{\mathrm{a}}$ \\
\hline$\Delta$ Asupan & $-31.44(-21.65-$ & $-36.59 \pm 38.17$ & $-33.56 \pm 57.32$ & $0.612^{b}$ \\
\hline Karbohidrat & 48.47 & & & \\
\hline$\Delta$ Asupan Kolesterol & $-112.92 \pm 198.17$ & $-72.61 \pm 152.74$ & $-68.05 \pm 145.67$ & $0.739^{\mathrm{a}}$ \\
\hline$\Delta$ Asupan Serat & $-0.99(-0.51-3.16)$ & $-0.78 \pm 1.81$ & $0.64 \pm 4.00$ & $0.238^{\mathrm{b}}$ \\
\hline
\end{tabular}

Tabel 7 menunjukkan tidak adanya perbedaan perubahan asupan energi, protein, lemak, karbohidrat, kolesterol dan serat ( $p>0.05$ ).

\section{Keadaan subjek pada akhir penelitian}

Keadaan subjek pada akhir penelitian setelah dilakukan intervensi dapat dilihat pada tabel 8.

Tabel 8. Keadaan subjek pada akhir penelitian

\begin{tabular}{|c|c|c|c|c|c|c|c|}
\hline \multirow{2}{*}{\multicolumn{2}{|c|}{ Kadar pengukuran }} & \multicolumn{4}{|c|}{ Rerata (mean \pm SD) } & \multirow[t]{2}{*}{$\min$} & \multirow{2}{*}{$\begin{array}{l}\text { mak } \\
\mathrm{s}\end{array}$} \\
\hline & & Kontro & & Perlakuan I & Perlakuan II & & \\
\hline $\begin{array}{l}\text { Kolesterol } \\
(\mathrm{mg} / \mathrm{dl})\end{array}$ & total & 233.07 & 3.20 & $\begin{array}{l}223.57 \pm 21.4 \\
0\end{array}$ & $225.00 \pm 33.60$ & 152 & 314 \\
\hline $\begin{array}{l}\text { Trigliserida } \\
(\mathrm{mg} / \mathrm{dl})\end{array}$ & & $\begin{array}{l}135.85 \\
79.60)\end{array}$ & (111.00- & $\begin{array}{l}199.07 \pm 113 \text {. } \\
94\end{array}$ & $195.57 \pm 108.82$ & 54 & 482 \\
\hline
\end{tabular}

Tabel 9. Kadar kolesterol total dan trigliserida pada akhir penelitian

\begin{tabular}{lccccccc}
\hline Kadar pengukuran & & \multicolumn{2}{c}{ Kontrol } & \multicolumn{2}{c}{ Perlakuan I } & \multicolumn{2}{c}{ Perlakuan II } \\
\hline & & $\mathrm{n}$ & $\%$ & $\mathrm{n}$ & $\%$ & $\mathrm{n}$ & $\%$ \\
\hline $\begin{array}{l}\text { Kolesterol total } \\
\text { (mg/dl) }\end{array}$ & $>200$ & 13 & 92.8 & 12 & 85.7 & 12 & 85.7 \\
& & & 6 & & 1 & & 1 \\
& $<200$ & 1 & 7.14 & 2 & 14.2 & 2 & 14.2 \\
& & & & & 9 & & 9 \\
Trigliserida (mg/dl) & $>150$ & 4 & 28.5 & 9 & 64.2 & 7 & 50 \\
& & & 7 & & 9 & & \\
& $<150$ & 10 & 71.4 & 5 & 35.7 & 7 & 50 \\
& & & 3 & & 1 & & \\
\hline
\end{tabular}

Pada tabel 9 terlihat kadar kolesterol total subjek penelitian sebagian besar masih tinggi walaupun terjadi penurunan kadar kolesterol dari kadar kolesterol yang tinggi menjadi normal pada subjek penelitian. Kadar trigliserida subjek 
penelitian pada akhir penelitian sebagian besar subjek memiliki kadar trigliserida yang normal.

\section{Pengaruh konsumsi Black Soyghurt terhadap kadar kolesterol total dan Trigliserida}

Tabel 10 menggambarkan pengaruh konsumsi Black Soyghurt terhadap kadar kolesterol total

Tabel 10. Pengaruh pemberian Black Soyghurt terhadap kadar kolesterol total masing-masing kelompok sebelum dan sesudah intervensi

\begin{tabular}{llclcc}
\hline \multicolumn{1}{c}{ Kelompok } & \multicolumn{1}{c}{$\begin{array}{c}\text { Sebelum } \\
(\mathrm{mg} / \mathrm{dl})\end{array}$} & $\begin{array}{c}\text { Sesudah } \\
(\mathrm{mg} / \mathrm{dl})\end{array}$ & \multicolumn{1}{c}{$\Delta$} & $\Delta \%$ & $\mathrm{p}$ \\
\hline Kontrol & $239.29 \pm 35.16$ & $233.07 \pm 33.20$ & - & $-2.12 \%$ & $0.303^{\mathrm{a}}$ \\
& & & $6.21 \pm 21.36$ & & \\
Perlakuan I & $228.21 \pm 22.07$ & $223.57 \pm 21.40$ & - & $-1.64 \%$ & $0.431^{\mathrm{a}}$ \\
& & & $4.64 \pm 21.36$ & & \\
Perlakuan 2 & $225.93(211.50-$ & $225.00 \pm 33.60$ & - & $-0.05 \%$ & $0.875^{\mathrm{b}}$ \\
& $266)$ & & $093 \pm 31.18$ & & \\
\hline
\end{tabular}

${ }^{\mathrm{a}} \mathrm{Uji}$ Paired t test

${ }^{\mathrm{b}}$ Uji Wilcoxon

Tabel 10 menunjukkan secara statistik tidak ada perbedaan kadar kolesterol total sebelum dan setelah intervensi pada ketiga kelompok ( $>0.05)$. Secara deskriptif terdapat penurunan kadar kolesterol total pada ketiga kelompok, dimana penurunan terbesar terjadi pada kelompok kontrol.

Pengaruh pemberian Black Soyghurt terhadap penurunan kadar Trigliserida ditampilkan pada tabel 11.

Tabel 11. Pengaruh pemberian Black Soyghurt terhadap kadar Trigliserida masing-masing kelompok sebelum dan setelah intervensi

\begin{tabular}{llllll}
\hline Kelompok & $\begin{array}{l}\text { Sebelum } \\
\text { (mg/dl) }\end{array}$ & $\begin{array}{l}\text { Sesudah } \\
(\mathbf{m g} / \mathbf{d l})\end{array}$ & $\Delta$ & $\Delta \%$ & $\mathbf{p}$ \\
\hline Kontrol & $166.07(136.5-96.27)$ & $135.85(111.00-$ & $-30.21(14.00-$ & - & $0.073^{\mathrm{b}}$ \\
& & $79.60)$ & $11)$ & $13.02 \%$ & \\
Perlakuan & $207.79(171.00) 132.76$ & $199.07 \pm 113.94$ & $-8.17 \pm 137.25$ & $-7.85 \%$ & $0.925^{\mathrm{b}}$ \\
$\begin{array}{l}\text { I } \\
\text { Perlakuan }\end{array}$ & $\begin{array}{l}190.79(166.50- \\
2\end{array}$ & $195.57 \pm 108.82$ & $4.79 \pm 122.67$ & $0.13 \%$ & $0.826^{\mathrm{b}}$ \\
\hline \multicolumn{2}{c}{ bj Uji Wilcoxon } & & & & \\
\hline
\end{tabular}

Tabel 11 menunjukkan secara statistik terdapat tidak terdapat perbedaan kadar Trigliserida yang bermakna pada masing-masing kelompok ( $>00.05)$. Secara deskriptif terjadi penurunan kadar Trigliserida pada kelompok kontrol dan perlakuan I, dimana penurunan yang terbesar terjadi pada kelompok kontrol. Sementara pada kelompok perlakuan II terjadi peningkatan kadar Trigliserida.

\section{Pengaruh konsumsi Black Soyghurt terhadap rerata perubahan kadar kolesterol total dan Trigliserida \\ Pengaruh konsumsi Black Soyghurt} terhadap rerata perubahan kolesterol total dan Trigliserida antar ketiga kelompok ditampilkan pada tabel 12 .

Tabel 12. Perbedaan rerata perubahan kadar kolesterol total dan trigliserida antar ketiga kelompok

\begin{tabular}{lcccc}
\hline$\Delta(\mathrm{mg} / \mathrm{dl})$ & Kontrol & Perlakuan I & Perlakuan II & $\mathrm{p}$ \\
\hline$\Delta$ kolesterol total & $-6.21 \pm 21.70$ & $-4.64 \pm 21.36$ & $-0.93 \pm 31.18)$ & $0.850^{\mathrm{a}}$ \\
$\Delta$ Trigliserida & $-30.21(14.00-$ & $-8.71 \pm 137.25$ & $4.79 \pm 122.67$ & $0.770^{\mathrm{b}}$ \\
& $52.11)$ & & & \\
\hline
\end{tabular}


${ }^{a}$ Uji beda ANOVA

${ }^{\mathrm{b}}$ Uji Kruskal-Wallis

Tabel 12 Menunjukkan tidak adanya perbedaan pengaruh pemberian Black Soyghurt terhadap kadar kolesterol total dan trigliserida antara ketiga kelompok ( $\mathrm{p}>0.05)$.

\section{Analisis Regresi beberapa variabel perancu terhadap kadar kolesterol total dan trigliserida pada masing-masing kelompok}

Analisis regresi beberapa variabel perancu terhadap kadar kolesterol total pada masingmasing kelompok dapat dilihat pada tabel 13.

Tabel 13. Analisis regresi beberapa variabel perancu terhadap kadar kolesterol total pada masing-masing kelompok

\begin{tabular}{llcc}
\hline Kelompok & \multicolumn{1}{c}{ Variabel yang berpengaruh } & Adjusted R & $\mathrm{p}$ \\
\hline Kontrol & Asupan Karbohidrat & 0.292 & 0.049 \\
\hline Perlakuan I & \multicolumn{1}{c}{--} & - & - \\
\hline Perlakuan II & Asupan kolesterol & 0.610 & 0.005 \\
& Asupan serat & & 0.015 \\
\hline
\end{tabular}

*uji regresi ganda

Variabel independent : usia, IMT, asupan energi, protein, lemak, karbohidrat, kolesterol dan serat Variabel dependent: kadar kolesterol total

Tabel 13 menunjukkan nilai adjusted $\mathrm{R}$ pada kelompok kontrol adalah 0.292 yang artinya sebesar $29.2 \%$ variabel perancu antara lain usia, IMT,dan asupan selama intervensi mempengaruhi kadar kolesterol total, sisanya sebesar $70.8 \%$ dipengaruhi oleh variabel lain yang tidak diteliti, tetapi variabel perancu yang paling mempengaruhi adalah asupan karbohidrat. Pada kelompok perlakuan I variabel perancu tidak mempengaruhi terhadap kadar kolesterol total, sedangkan nilai adjusted R pada kelompok perlakuan II adalah 0.610 yang artinya sebesar $61 \%$ variabel perancu mempengaruhi kadar kolesterol total dan sisanya $39 \%$ dipengaruhi oleh variabel lain yang tidak diteliti, tetapi variabel yang paling mempengaruhi adalah asupan kolesterol dan serat selama intervensi.

Analisis regresi beberapa variabel perancu kadar trigliserida pada masing-masing kelompok dapat dilihat pada tabel 14 .

Tabel 14. Analisis regresi beberapa variabel perancu terhadap kadar trigliserida pada masing-masing kelompok

\begin{tabular}{llcc}
\hline Kelompok & \multicolumn{1}{c}{ Variabel yang berpengaruh } & Adjusted R & $\mathrm{p}$ \\
\hline Kontrol & IMT & 0.728 & 0.012 \\
& Asupan energi & & 0.005 \\
& Asupan protein & & 0.004 \\
& Asupan lemak & & 0.009 \\
& Asupan karbohidrat & & 0.004 \\
& Asupan serat & & 0.025 \\
\hline Perlakuan I & & - & \\
\hline Perlakuan II & Asupan energi & 0.435 & 0.034 \\
& Asupan serat & & 0.007 \\
\hline
\end{tabular}

"uji regresi ganda

Variabel independent : usia, IMT, asupan energi, protein, lemak, karbohidrat, kolesterol dan serat Variabel dependent: kadar kolesterol total

Tabel 14 menunjukkan nilai adjusted $\mathrm{R}$ pada kelompok kontrol adalah 0.728 yang artinya sebesar $72.8 \%$ variabel perancu mempengaruhi kadar trigliserida dan sisanya sebesar $27.2 \%$ dipengaruhi oleh variabel lain yang tidak diteliti, tetapi variabel yang paling mempengaruhi adalah IMT, variabel energi, protein, lemak, karbohidrat dan serat. Pada kelompok perlakuan I tidak 
terdapat variabel perancu yang mempengaruhi kadar trigliserida sedangkan nilai adjusted $\mathrm{R}$ pada kelompok perlakuan II adalah 0.435 yang artinya sebesar $43.5 \%$ variabel perancu mempengaruhi kadar trigliserida dan sisanya $56.5 \%$ dipengaruhi oleh variabel lain yang tidak diteliti, tetapi variabel yang paling mempengaruhi yaitu asupan energi dan serat.

\section{PEMBAHASAN}

Karakteristik subjek dalam penelitian ini adalah laki-laki dengan dislipidemia dan berusia 40 tahun ke atas. Sebagian besar subjek (57.14\%) berada pada kelompok usia 51- 60 tahun, sementara status gizi subjek sebagian besar (73.8\%) adalah overweight dan obesitas I. Namun, secara keseluruhan tidak terdapat perbedaan karakteristik subjek pada awal penelitian.

Gambaran kelompok usia subjek dalam penelitian ini adalah 40-55 tahun sesuai dengan penelitian yang dilakukan di Surabaya tahun 2006, bahwa kadar kolesterol yang tinggi berhubungan dengan usia. ${ }^{12}$ Selain itu penelitian di China juga menunjukkan bahwa dislipidemia pada pria meningkat seiring dengan bertambahnya usia, ${ }^{13}$ hal ini disebabkan adanya penurunan hormon testosteron yang dapat meningkatkan risiko dislipidemia. ${ }^{14}$ Hormon testosteron yang rendah juga berkaitan dengan risiko terjadinya penyakit aterosklerosis pada pria. ${ }^{111}$ Status gizi juga merupakan faktor yang berpengaruh terhadap profil lipid. Pada penelitian ini sebagian besar subjek mempunyai status gizi obesitas I yang sesuai dengan penelitian yang dilakukan di Mesir. ${ }^{15}$ Pada penderita obesitas sering terjadi gangguan metabolisme lipoprotein sehingga dapat menyebabkan peningkatan kadar kolesterol darah. $^{16,17}$

Gambaran asupan makan sebelum dan selama intervensi menunjukkan sebagian besar subjek memiliki asupan makan dalam kategori kurang yang meliputi asupan energi, protein, lemak, karbohidrat, kolesterol dan serat dikarenakan penelitian ini dilakukan pada saat bulan puasa sehingga asupan seseorang cenderung rendah. Angka kecukupan yang dianjurkan utuk pria dengan kelompok usia 40-55 tahun dengan aktivitas fisik yang rendah berdasarkan Angka Kecukupan Gizi (AKG) 2004 untuk energi adalah 2200 kkal dan protein 60 gram. $^{18}$ Asupan serat pada semua subjek penelitian dalam kategori $<20$ g/hari. Angka kecukupan serat per hari yang direkomendasikan American Heart Association (AHA), yaitu 20-35 gram/hari. ${ }^{19}$
Perubahan asupan makan sebelum dan selama penelitian antar kelompok tidak menunjukkan adanya perbedaan yang bermakna, walaupun secara deskriptif pada masing-masing kelompok terdapat penurunan dalam asupan makan. Perbedaan asupan makan sebelum dan selama penelitian pada masing-masing kelompok yang dilihat dari rerata asupan terdapat beberapa asupan yang memiliki perbedaan yang bermakna. Pada kelompok kontrol terdapat perbedaan bermakna pada asupan karbohidrat, pada kelompok perlakuan I perbedaan yang bermakna terdapat pada asupan energi, protein , lemak, dan karbohidrat, sedangkan pada kelompok perlakuan II perbedaan yang bermakna terdapat pada asupan energi, protein, lemak dan karbohidrat.

Black soyghurt merupakan produk fermentasi susu kedelai hitam oleh bakteri asam laktat. $^{8}$ Kedelai hitam memiliki kandungan antioksidan yaitu isoflavon dan anthosianin. ${ }^{20}$ Isoflavon yang terkandung dalam kedelai merupakan sterol yang berasal dari tumbuhan (fitosterol) yang apabila dikonsumsi dapat menghambat absorbsi kolesterol, baik yang berasal dari diet maupun kolesterol yang diproduksi dari hati. ${ }^{21}$ Isoflavon pada kedelai menunjukkan reaksi ketika senyawa tersebut terikat dengan protein. Peran protein kedelai dalam menurunkan kadar kolesterol darah melalui peningkatan ekskresi steroid dalam feses dan asam empedu, sehingga kadar kolesterol darah menurun. Isoflavon kedelai mampu menghambat $\beta$-hidroksiB-metilglutaril koenzim A (HMG-CoA) ${ }^{22}$ HMGCoA merupakan enzim utama dalam sintesis kolesterol dan asil-CoA intestinal. Enzim tersebut berperan dalam esterifikasi kolesterol, sebelum kolesterol diserap dan diubah menjadi kilomikron dalam usus. Selain itu, isoflavon juga menurunkan kelarutan misel, absorbsi kolesterol dan asam empedu dalam usus. Penurunan kadar kolesterol, berkaitan dengan lambatnya absorbsi asam lemak non esensial dalam isoflavon kedelai, sehingga ketersediaan asetil CoA untuk sintesis kolesterol juga rendah. ${ }^{23}$

Kedelai juga mengandung asam lemak tak jenuh ganda (PUFA) yang dapat menyebabkan kadar kolesterol total dalam darah menjadi berkurang karena cepat dimetabolisme oleh hati dan terjadi peningkatan eksresi dan stimulasi oksidasi kolesterol dalam garam empedu sehingga terjadi penurunan kadar kolesterol total. Kandungan lain yang mempunyai efek menurunkan kadar kolesterol adalah serat. Adanya serat larut maupun tidak larut dalam diet dapat 
menurunkan kadar kolesterol total darah, karena salah satu fungsi serat adalah menghambat absorbsi kolesterol makanan dalam lumen usus. ${ }^{24}$

Anthosianin merupakan salah satu senyawa flavonoid yang merupakan komponen utama warna hitam pada kulit kedelai hitam. ${ }^{25}$ Flavonoid merupakan senyawa yang memiliki aktivitas antihiperlipid dan antioksidan. Beberapa penelitian mengenai flavonoid menyatakan aktivitas hipolipidemik dan antioksidan adalah anthosianin yang memiliki warna ungu sampai hitam pada buah. Flavonoid pada kulit kedelai hitam diteliti memiliki berbagai aktivitas dalam menghambat terjadinya plak aterosklerosis pada pembuluh darah melalui berbagai mekanisme. Flavonoid membantu pengeluaran kolesterol dari jaringan perifer menuju hepar untuk selanjutnya dikeluarkan melalui eksresi bilier. ${ }^{26}$

Pemberian black soyghurt selama 21 hari terjadi penurunan kadar kolesterol total sebesar $1.64 \%$ pada kelompok perlakuan I dengan dosis pemberian $115 \mathrm{ml}$ dan $0.05 \%$ pada kelompok perlakuan II dengan dosis pemberian $225 \mathrm{ml}$. Penurunan kadar kolesterol total juga terjadi pada kelompok kontrol sebesar $2.12 \%$. Secara statistik pada ketiga kelompok tidak terdapat penurunan yang bermakna.

Penurunan kadar kolesterol paling besar terjadi pada kelompok kontrol. Hasil analisis regresi pada kelompok kontrol, kadar kolesterol total dipengaruhi oleh asupan karbohidrat ditunjukkan dengan rerata yang asupan yang lebih rendah dibandingkan dengan kelompok perlakuan I dan II.

Pada kelompok perlakuan I variabel perancu tidak mempengaruhi kadar kolesterol total sehingga menyebabkan penurunan kadar kolesterol total pada kelompok perlakuan I lebih besar daripada kelompok perlakuan II, sedangkan pada kelompok perlakuan II asupan energi dan serat mempunyai pengaruh terhadap kadar kolesterol total ditunjukkan dengan perubahan asupan energi dan serat lebih rendah dibandingkan kelompok kontrol dan perlakuan I.

Pengaruh perlakuan terhadap kadar trigliserida diperoleh hasil bahwa penurunan kadar trigliserida terjadi pada kelompok kontrol sebesar $13.02 \%$ dan perlakuan I sebesar $7.85 \%$, namun secara statistik tidak menunjukkan adanya perbedaan yang bermakna. Berdasarkan hasil penelitian diketahui bahwa kadar trigliserida serum berkorelasi positif dengan kadar kolesterol serum, sehingga apabila terjadi penurunan kadar kolesterol biasanya juga akan diikuti dengan penurunan kadar trigliserida. ${ }^{27}$

Penurunan kadar trigliserida paling besar terjadi pada kelompok kontrol. Hasil analisis regresi pada kelompok kontrol kadar trigliserida dipengaruhi oleh IMT, asupan energi, protein, lemak, karbohidrat dan serat ditunjukkan dengan rerata asupan energi, lemak, karbohidrat, dan serat lebih rendah dibandingkan kelompok perlakuan sehingga menyebabkan penurunan kadar trigliserida lebih besar dibandingkan kelompok perlakuan I dan II. Asupan protein pada kelompok kontrol mempunyai rerata lebih besar daripada kelompok perlakuan I dan II. Menurut sebuah penelitian metaanalisis terhadap 38 uji klinis menyatakan protein pada kacang kedelai mampu menurunkan kadar kolesterol dan trigliserida. ${ }^{6}$

Pada kelompok perlakuan I variabel perancu tidak mempengaruhi kadar trigliserida sehingga menyebabkan penurunan kadar trigliserida lebih besar daripada kelompok perlakuan II.

Pada kelompok perlakuan II terjadi peningkatan kadar trigliserida sebesar $0.13 \%$. Hasil regresi menunjukkan bahwa asupan energi dan serat mempengaruhi kadar trigliserida pada kelompok perlakuan II, ditunjukkan dengan rerata asupan energi lebih besar dibandingkan kelompok kontrol dan perlakuan II sehingga menyebabkan peningkatan kadar trigliserida. Asupan energi yang tinggi mempengaruhi sekresi VLDL. ${ }^{4}$

Peningkatan kadar trigliserida dapat disebabkan oleh beberapa faktor diantaranya kebiasaan merokok, aktivitas fisik yang rendah, dan konsumsi yoghurt yang tepat. Pada penelitian ini telah dilakukan pengontrolan terhadap faktorfaktor tersebut seperti kebiasaan merokok melalui pemilihan subjek penelitian dengan kebiasaan merokok < 10 batang per hari karena menurut penelitian orang yang merokok $>10$ batang/hari memiliki risiko 2-3x lebih tinggi mengalami penyakit jantung koroner, ${ }^{28}$ tetapi pada saat intervensi dilakukan subjek penelitian tidak dipantau jumlah rokok yang dihisap tiap harinya. Merokok menjadi salah satu faktor yang dapat meningkatkan kadar trigliserida karena nikotin yang terkandung dalam asap rokok akan merangsang hormon adrenalin, sehingga akan mengubah metabolisme lemak dan dapat merusak lapisan endotel di pembuluh darah. ${ }^{30}$ Konsumsi yoghurt yang tepat bermanfaat dalam menurunkan kadar kolesterol. Menurut penelitian terdahulu konsumsi yoghurt yang tepat dan efektif untuk menurunkan kadar kolesterol yaitu apabila 
dikonsumsi diluar waktu makan, tetapi pada penelitian ini peneliti tidak dapat memantau waktu konsumsi yoghurt pada subjek penelitian. Aktivitas fisik yang rendah dapat menyebabkan peningkatkan kadar kolesterol dan trigliserida. ${ }^{29}$ Pada penelitian ini, peneliti tidak melakukan pemantauan aktivitas fisik. Pemantauan aktivitas fisik pada subjek penelitian hanya dilakukan pada saat skrining untuk memenuhi kriteria inklusi subjek penelitian.

Pada penelitian ini penurunan kadar kolesterol total dan trigliserida paling besar terdapat pada kelompok kontrol walaupun secara statistik tidak signifikan. Pada kelompok kontrol tidak dilakukan intervensi dengan pemberian yoghurt kedelai hitam dan hanya diberikan konseling seperti pada kelompok perlakuan sehingga subjek penelitian lebih memiliki kesadaran dalam pengendalian asupan makan ditunjukkan dengan rata-rata asupan makan yang lebih rendah dibandingkan kelompok perlakuan I dan II sehingga menyebabkan penurunan kadar kolesterol total dan trigliserida.

\section{KETERBATASAN PENELITIAN}

1. Tidak dilakukan uji kandungan zat bioaktif seperti kadar anthosianin dan isoflavon pada produk black soyghurt

2. Pemantauan aktivitas fisik hanya dilakukan pada saat pemilihan subjek penelitian tetapi selama penelitian subjek tidak dilakukan pemantauan aktivitas fisik.

3. Penelitian dilakukan selama bulan puasa sehingga asupan makan subjek penelitian cenderung berbeda dengan asupan keseharian subjek

4. Konsumsi black soyghurt hanya dilihat secara subjektif karena peneliti tidak dapat melihat secara langsung saat subjek mengkonsumsi kemungkinan konsumsi pada waktu yang tidak tepat seperti bersamaan pada waktu makan.

\section{KESIMPULAN}

Pada kelompok kontrol terjadi penurunan yang paling besar pada kadar kolesterol sebesar $2.12 \%$ dan penurunan kadar trigliserida sebesar 13.02\%. Pemberian black soyghurt pada dosis 115 ml selama 21 hari dapat menurunkan kadar kolesterol total sebesar $1.64 \%$ dan trigliserida $7.85 \%$. pemberian black soyghurt pada dosis 225 $\mathrm{ml}$ dapat menurunkan kadar kolesterol total sebesar $0.05 \%$ dan terjadi peningkatan trigliserida sebesar $0.13 \%$. Pada ketiga kelompok tidak terdapat penurunan yang bermakna secara statistik.
Beberapa variabel perancu ternyata memiliki pengaruh pada kelompok kontrol dan perlakuan II antara lain IMT, asupan energi, protein, lemak, karbohidrat, kolesterol dan serat.

\section{SARAN}

1. Penelitian lebih lanjut perlu dilakukan dengan subjek penelitian tidak hanya pada laki-laki dislipidemia, sehingga peran black soyghurt dalam menurunkan kadar kolesterol dapat dimanfaatkan secara umum.

2. Perlu dilakukan uji organoleptik untuk meningkatkan daya terima serta dilakukan uji kandungan zat bioaktif seperti anthosianin dan isoflavon

3. Perlu adanya pengontrolan pada faktor perancu seperti aktivitas fisik, merokok, konsumsi kopi dan asupan makan dan dilakukan pengawasan selama penelitian karena memiliki pengaruh yang besar terhadap perubahan kadar kolesterol dan trigliserida.

4. Penelitian dilakukan tidak pada bulan puasa untuk lebih mendapatkan hasil yang efektif dan asupan makan menggambarkan asupan makan sehari-hari subjek penelitian

5. Untuk subjek penelitian disarankan untuk mengatur pola makan dengan melakukan diet rendah lemak, peningkatan aktivitas fisik seperti olahraga, tidak merokok dan mengkonsumsi kopi sehingga akan mempengaruhi penurunan kadar kolesterol

\section{DAFTAR PUSTAKA}

1. Anwar TB. Dislipidemia sebagai Faktor Resiko Penyakit Jantung Koroner. Sumatera Utara: FK Universitas Sumatera Utara: 2004.

2. Kamso S, Purwantiyastuti, Juwita R. Dislipidemia pada lanjut usiadi kota Padang.Makara, kesehatan, vol 6, no.2. desember 2002.

3. Soendoro T. Riset Kesehatan Dasar 2007.Jakarta: Badan Penelitian dan Pengembangan Departemen Kesehatan.2008.

4. Mayes PA. Sintesis, pengangkutan, dan ekskresi kolesterol. In: Murray RK, Granner DK, Mayes PA, Rodwell VW, editors. Biokimia harper. $25^{\text {th }}$ ed. Jakarta: EGC; 2003.p.239-49

5. Wong WW, Smith EO, Stuff JE, Hachey DL, Heird WC, Pownell HJ. Cholesterol-lowering effect of soy protein in normocholesterolemic and hypercholesterolemic men. Am J Clin Nutr 1998;68 Suppl :1385S-9S.

6. Anderson JW, Johnstone BM, Cook-Newell ME. Meta-analysis of the effects of soy protein intake on serum lipids. N Engl J Med 1995;333:276-2.

7. Laili N, Luqman EM, Lukismanto BS. The effect of black soybean milk on liver to recovery 
histopathology in Rat with high fat diet. Artikel Ilmiah Surabaya: FKH Universitas Airlangga; 2009.

8. Nuryati S. Aktivitas antioksidan dan daya terima minuman probiotik kedelai hitam (Glycine soja). Artikel Ilmiah Mahasiswa Program Studi Ilmu Gizi. FK Undip Semarang; 2010.

9. Chien HL, Huang HY, and Chou CC. Transformation of isoflavonephytoestrogens during the fermentation of soymilk with lactic acid bacteria and bifidobacteria.Food Microbiol.23: 772-8.2006.

10. Riyanto S. P Yoghurt Pengaruh Pemberian Yoghurt Kedelai Hitam (Black Soyghurt) Terhadap Profil Lipid Tikus Hiperkolesterolemai. Artikel Penelitian Mahasiswa Program Studi Ilmu Gizi. FK Undip Semarang; 2011.

11. Alberta Medical Association. Building Healthy Lifestyles Vascular Protection Dyslipidemia Clinical Guide ; 2006.

12. Listiana L, Purbosari TY. Kadar Kolesterol Total pada Usia 25-60 tahun.Artikel Penelitian.2006.

13. Xiao GY, et all. The Prevalence of Hypertention, Obesity and Dyslipidemia in Individuals of over 30 years of age belonging to minorities from the pasture area of Xinjiang.BMC Public Health.2010.

14. Haring R, Baumeister SE, Volzke H, Dorr M, Felix $\mathrm{SB}$, Kroemer HK, et al. European Journal of Cardiovaskular Prevention \& Rehabilitation. 2011, 18(1):86-96.

15. Ella NARA, Shehab DI, Ismail MA. Prevalencce of Overweight and Obesity, and Status of Chronic noncommunicable Diseases and some related Risk Factors among Egyptian Adolescents. J Diabetes Endicronol.2010.

16. Fletcher B, Berra K, Ades P, Braun LT, Burke LE, Durstine JL, et al. Managing abnormal blood lipids, a collaborative approach. Circulation. 2005;112:3184-3209.

17. Anwar TB. Penyakit Jantung Koroner dan Hipertensi. Sumatera Utara: FK Universitas Sumatera Utara: 2004.

18. Tabel Angka Kecukupan Gizi (AKG) 2004.

19. Dreher ML. Dietary Fiber Overview. Indiana : Mead Johnson Nutritionals/Bristol-Myers Squibb Company, Evansville. 2001.

20. Michihiro S. Soy in health and disease prevention. New York: Taylor and Francis Group; 2006.

21. Silalahi, J. 2000. Fats, Oil and Fat substitutes in Human Nutrition. Indonesian Food and Nutrition Process.2000;7(2).p55-56.

22. Chan, P.T., et all. Jasmine green tea epicatechins are hypolipidemic in hamsters (Mesocricetus auratus) fed a high fat diet. J. Nuir 129: 10941101.1999.

23. Song, T., Barua, K., Buseman, G. and Murphy, P.A. Soy isoflavone analysis: quality control and a new internal standard. Am J. Clin Nutr 68: 1474s1479s.1998.

24. Krummel DA. Medical Nutrition Therapy in Cardiovascular Disease. In Mahan LK, Escott-stump
S. Krause's food, Nutrition, and Diet Therapy $13^{\text {th }}$ edition. Philadelphia: WB Saunders Company;2008. p.833-64.

25. El-Beshbishy HA, Singab AN, Sinkkonen J, Pihlaja $\underline{\mathrm{K}}$. Hypolipidemic and antioxidant effects of Morus alba L. (Egyptian mulberry) root bark fractions supplementation in cholesterol-fed rats. Cairo: Department of Biochemistry, Faculty of Pharmacy, Al-Azhar University.

26. Fuhrman B, Aviram M. Flavonoids protect LDL from oxidation and attenuate atherosclerosis. Curr Opin Lipidol 2001;12:41-8.

27. Maryanto S, Muis SF. Pengaruh pemberian jambu biji (Psidium guajava L) pada lipid serum tikus (Sprague Dawley) Hiperkolesterolemi. MMI 2004:39(2):105-11.

28. Erikseen J, Enger SC,. Smoking, lung function, physical performance and latent coronary heart disease in presumably healthy middle aged men. Acta Med Scan 1978; 203 : 509-516.

29. Karyadi E. Kiat Mengatasi Diabetes, Hiperkolesterolemia, Stroke. Jakarta: PT Intisari Mediatama; 2006: 53-7,59-61,63-4,73.

30. Suharto.Serangan Jantung dan Stroke.Jakarta: Gramedia Pustaka Utama;2004. 